\title{
ICNP $^{\circledR}$ terminology subset to infants in Primary Health Care
}

\author{
Subconjunto terminológico da CIPE ${ }^{\circledR}$ para o lactente na Atenção Primária à Saúde \\ Subconjunto terminológico de CIPE ${ }^{\circledR}$ para lo lactante en la Atención Primaria de Salud
}

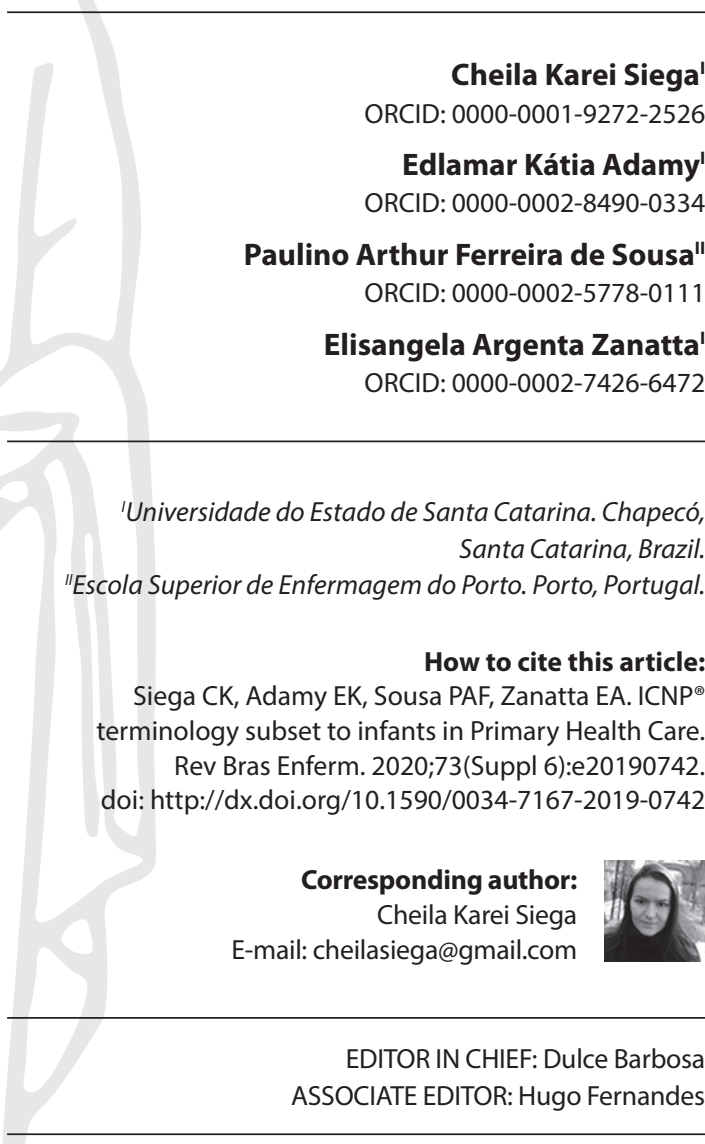

Submission: $01-22-2020$

Approval: 07-04-2020

\begin{abstract}
Objectives: to describe the development of an ICNP® terminology subset for Nursing Consultation to infants in Primary Health Care. Methods: a methodological study, described in five stages, carried out from May to September 2018 with 15 nurses who identified diagnoses, results, interventions, and validated the subset content. Results: the subset developed consists of 86 nursing diagnoses and results and 178 interventions, organized in the fields of Theory of Basic Human Needs. Final Considerations: the subset contributed to implement the systematized Nursing Consultation, assisting nurses in decision making. Construction and validation consolidate evidence-based practice, bringing the subset closer to practical reality, in addition to contributing to infant health care qualification.

Descriptors: Infant; Primary Health Care; Standardized Nursing Terminology; Nursing Theory; Nursing Process.
\end{abstract}

\section{RESUMO}

Objetivos: descrever o desenvolvimento de um subconjunto terminológico da CIPE ${ }^{\circledast}$ para a Consulta de Enfermagem ao lactente na Atenção Primária à Saúde. Métodos: estudo metodológico, descrito em cinco etapas, realizado de maio a setembro de 2018 com 15 enfermeiros que identificaram diagnósticos, resultados, intervenções e validaram o conteúdo do subconjunto. Resultados: o subconjunto desenvolvido é composto por 86 diagnósticos e resultados de enfermagem e 178 intervenções, organizado nos campos da Teoria das Necessidades Humanas Básicas. Considerações Finais: o subconjunto contribuiu para a implementação da Consulta de Enfermagem sistematizada, auxiliando o enfermeiro na tomada de decisão. A construção e a validação realizadas consolidam a prática baseada em evidências, aproximando o subconjunto da realidade prática, além de contribuir para a qualificação da assistência à saúde do lactente.

Descritores: Lactente; Atenção Primária à Saúde; Terminologia Padronizada em Enfermagem; Teoria de Enfermagem; Processo de Enfermagem.

\section{RESUMEN}

Objetivos: describir el desarrollo de un subconjunto terminológico de CIPE ${ }^{\oplus}$ para la Consulta de Enfermería para lactantes en Atención Primaria de Salud. Métodos: estudio metodológico, descrito en cinco etapas, realizado de mayo a septiembre de 2018 con 15 enfermeras que identificaron diagnósticos, resultados, intervenciones y validado el contenido del subconjunto. Resultados: el subconjunto desarrollado consta de 86 diagnósticos y resultados de enfermería y 178 intervenciones, organizadas en los campos de Teoría de las Necesidades Humanas Básicas. Consideraciones Finales: el subconjunto contribuyó a la implementación de la Consulta de Enfermería sistematizada, ayudando a la enfermera en la toma de decisiones. La construcción y validación llevadas a cabo consolidan la práctica basada en la evidencia acercando el subconjunto a la realidad práctica, además de contribuir a la calificación de la atención de salud infantil.

Descriptores: Lactante; Atención Primaria de Salud; Terminología Normalizada de Enfermería; Teoría de Enfermería; Proceso de Enfermería. 


\section{INTRODUCTION}

Infant care, i.e., children older than one year ${ }^{(1)}$, is important in determining their quality of life. It is in childhood that cognitive, social and learning capacities are more sharply developed; however, dysfunctions in the body may arise which, when left untreated, are likely to cause negative consequences to the health of infants ${ }^{(2-3)}$.

In Brazil, population estimates made for 2018 showed that the number of children under one year old was $2,774,484$. Hospital morbidity records revealed an admission of $626,089(22.56 \%)$ of these children ${ }^{(4)}$. The main causes recorded are mainly related to conditions originating in the perinatal period; diseases of the respiratory, genitourinary, nervous and digestive systems; infectious and parasitic diseases; congenital malformations, deformities and chromosomal abnormalities; skin and subcutaneous tissue diseases; endocrine, nutritional and metabolic diseases ${ }^{(5)}$.

Thus, surveillance and monitoring of child growth and development are considered to be a fundamental strategy to promote the health of infants and detect diseases early ${ }^{(3)}$. This monitoring is, especially, developed in the scope of Primary Health Care (PHC) in performing childcare Nursing Consultation (NC). Childcare aims to identify individual and comprehensive health needs; carry out periodic and systematic monitoring of growth and development; provide care; assess the results; promote child health and, consequently, reduce child morbidity and mortality $(2,6-7)$.

Health promotion actions carried out by nurses, during Childcare NC, are evidenced by attitudes that go beyond technicist practice. They cover the family, environmental, social, economic and cultural context of families, in addition to promoting health education, favoring child growth and development through a comprehensive view ${ }^{(2)}$.

In this regard, there is a growing interest and concern in building a language that can support the performance of nurses systematized and recognized worldwide. Thus, the International Classification for Nursing Practice (ICNP ${ }^{\circledR}$ ) stands out as a tool to support effective clinical decision-making and in the description of professional practice in an organized way ${ }^{(8)}$. One of the ways to enhance ICNP ${ }^{\circledR}$ use is by building terminology subsets, consisting of statements of diagnoses, results and nursing interventions for a group of customers and selected health priorities ${ }^{(8-10)}$.

Considering that infant care requires a holistic and comprehensive view from nurses, this subset was built in light of Wanda Horta's Theory of Basic Human Needs $(\mathrm{BNH})^{(11)}$. A subset was not identified in the researched literature for this age group in PHC.

\section{OBJECTIVES}

To describe the development of an ICNP ${ }^{\circledR}$ terminology subset for NC to infants in PHC.

\section{METHODS}

\section{Ethical aspects}

The recommendations of Resolution 466 of 2012 were supported. This study was approved by a local Research Ethics Committee, under Opinion 2,630,923, on May 2, 2018.

\section{Type of study}

This is a methodological study recommended by the International Council of Nurses (ICN) ${ }^{(8)}$. It was described in five stages: identification of the focus/catalog customer; health priority documentation; ICNP ${ }^{\circledR}$ seven-axis model use; testing and validation with expert nurses; dissemination of an ICNP ${ }^{\circledR}$ terminology subset.

\section{Study and study participants}

This study is the result of a Professional Master's Degree Course in Nursing and is part of a research macro project entitled "Estratégias para a implementação da Sistematização da Assistência de Enfermagem no cuidado à mulher e à criança".

This study was carried out with 15 nurses working at PHC in a municipality in the Midwest of Santa Catarina, between May and September 2018. All nurses were selected through a search carried out in the Brazilian National Register of Health Facilities (Cadastro Nacional de Estabelecimentos de Saúde). Nurses and those working in child care at PHC were included. Nurses who were on leave due to leave or working in the position for less than six months were excluded.

\section{Collection, and organization and analysis of data}

Step 1 - Identification of the focus/catalog customer: infant, age group defined from the professional experiences of a master's student, when considering the need to contribute to the organization and improvement of child health care.

Step 2 - Documentation of health priority: the epidemiological profile of child health in the municipality was drawn up using the data available in the following Brazilian information systems: Mortality Information System (Sistema de Informação de Mortalidade), Live Birth Information System (Sistema de Informação sobre Nascidos Vivos), Hospital Information System of the Brazilian Health System (Sistema de Informações Hospitalares do Sistema Único de Saúde) and outpatient nature, in the health management system.

With these data in hand, four Focus Groups (FG) ${ }^{(12)}$ were carried out with 15 nurses to create an ICNP ${ }^{\circledR}$ terminology subset and to support the process of construction, discussion, testing and validation. The script for each FG and its conduction were carried out by a master's student, by two professors and by a Scientific Initiation student.

Step 3 - ICNP ${ }^{\circledR}$ seven-axis model use: in the first FG, discussions were held about Wanda Horta's theory ${ }^{(11)}$, its concepts, propositions and principles, which allowed incorporating the theoretical model chosen for the subset construction. In the second FG, identification of nursing diagnoses and results was carried out by using the ICNP ${ }^{\circledR}$ seven-axis model, 2017. The epidemiological profile, based on information systems, and empirical evidence were used nurses' experiences, to develop a list of relevant terms for infant care. For each empirical evidence or epidemiological data, terms were selected that integrate the Focus axis (area of attention relevant to nurses) and another one of the Judgment axis (clinical opinion or determination related to the focus of nursing practice), minimally; or even represented by a clinical 
Find (state, process, structure, function or altered behavior). The reference model of ISO 18.104:2014 is the basis for its writing. ICNP ${ }^{\circledR}$ pre-coordinated concepts were also used in the statements' final writing ${ }^{(13-14)}$.

In the third FG, nursing interventions were selected for each identified diagnosis, considering ISO 18.104: 2014 ${ }^{(13-14)}$ from the terms of the Action axis (intentional process applied to infants) and target terms (entity affected by action). Thus, when necessary, the actions were qualified using the terms that correspond to route, time, place, and subject according to ICNP ${ }^{\circledR}$ as well as pre-coordinated concepts, in their final writing.

In the fourth FG, the subset content was validated, which corresponds to Step 4 - Testing and validation with expert nurses. Nurses tested the subset, during NC performance in childcare, for 30 days. In this research, the participating nurses were considered expert nurses. After testing, the subset was validated using Content Validity Index (CVI) containing five questions, which was assessed individually. The result of the assessment with a score equal to or greater than 0.80 of agreement rate was established as acceptable ${ }^{(15)}$.

CVI uses a Likert scale with a score from one to four, namely: 1 Inadequate; 2 - Partially adequate; 3 - Adequate; 4 -Totally adequate. Score was calculated by adding the items'agreement, divided by the total number of responses. If any criteria did not reach the established agreement rate, the content would be revised for readjustment and, then, validation would be carried out ${ }^{(15)}$. There was no need for changes in this study, as the subset scored 1.0 (100\%).

Step 5 - Dissemination of the ICNP ${ }^{\circledR}$ terminology subset: the subset was incorporated into Childcare NC and triggered movements to create a working group and a strategy schedule to create the Municipal Child Health Protocol.

\section{RESULTS}

The data obtained from the municipality's health management system revealed the registration of 1,219 children under one year old, able to implement Childcare NC, in August 2018(16). From January to August 2018, the municipality registered hospitalizations for: infectious and parasitic diseases (17); nutritional and metabolic endocrine diseases (4); respiratory system diseases (32); digestive system diseases (16); skin and subcutaneous tissue diseases (2); genitourinary system diseases (2); diseases originating in the perinatal period (65); congenital malformations, deformities, and chromosomal abnormalities (5); symptoms, signs and abnormal clinical and laboratory findings (3); injuries, poisoning and some other consequences of external causes (2) $)^{(17)}$.
The reason for attending children in Basic Health Units (BHU) in the city, in 2018, was due to problems related to situations that affect BNH: diseases of the respiratory system (369); infectious and parasitic diseases (42); nutritional and metabolic endocrine diseases (15); diseases of the skin and subcutaneous tissue (62); digestive tract diseases (69)(16).

Thus, from the focuses of nursing care, the statements of diagnoses and the results of nursing were associated. For each nursing diagnosis identified, it was associated with nursing interventions resulting from Evidence-Based Practice (EBP) (scientific studies and / or experiences of nurses in childcare NC). ICNP ${ }^{\circledR}$ terminology subset for infants consisted of 86 nursing diagnoses and results and 178 nursing interventions, alphabetically ordered and conceptually organized, according to $\mathrm{BNH}^{(11)}$ (Chart 1).

\section{DISCUSSION}

Developing a terminology subset is essential to support the assistance of nurses in infant care, as it allows professionals to carry out a careful and anchored assessment in a Standardized Language System (SLS) that favors health promotion actions; early identification of changes and aggravations to child health; and understanding of the growth and development process by the family ${ }^{(3)}$.

The nurses' actions, guided by terminology subsets, contribute to the clinical reasoning, planning and assessment of actions carried out in childcare NC. In this regard, $\mathrm{ICN}^{(8)}$ proposes that the theoretical model chosen to structure a subset is at the discretion of the researcher, and should be in line with the practice, context, and customer. Thus, Wanda Horta's theory ${ }^{(11)}$ aligns with this subset when she understands health as a state of dynamic equilibrium that can be affected, requiring, therefore, care.

In this ICNP ${ }^{\circledR}$ terminology subset, psychobiological needs related to oxygenation and risk of changes in the respiratory system were identified. A study ${ }^{(18)}$ that analyzed the morbidity and mortality profile of high-risk neonates highlighted respiratory diseases as causing morbidities. Thus, in addition to the nursing interventions selected in this subset, it is important to highlight the need to check the infant's respiratory rate, as it is identified as one of the defining characteristics prevalent for respiratory infections ${ }^{(19)}$.

Infant nutrition, a psychobiological need identified in this subset, is also the subject of a study ${ }^{(20)}$ that described the profile of the population under one year of age attended in Childcare NC. It was evidenced that the majority of infants were eutrophic

Chart 1 - International Classification for Nursing Practice terminology subset for infants in Primary Health Care

\begin{tabular}{|c|c|}
\hline DAGNOSIS/ NURSING OUTCOMES & NURSING INTERVENTIONS \\
\hline \multicolumn{2}{|c|}{ PSYCHOBIOLOGICAL NEED - OXYGENATION } \\
\hline $\begin{array}{l}\text { Risk of impaired respiratory system } \\
\text { function }\end{array}$ & $\begin{array}{l}\text { Scheduling follow-up appointment; } \\
\text { Assessing whether infants are alert, active, fatigued, cyanotic, with inspiratory, expiratory difficulty, } \\
\text { expiratory groan; } \\
\text { Referring to appointment with medical professional; } \\
\text { Identifying the presence of cough and its characteristics, nasal congestion, fever above } 38^{\circ} \mathrm{C} \text {, vomiting, } \\
\text { diarrhea, abdominal pain; } \\
\text { Auscultating; } \\
\text { Requesting family monitoring by a Community Health Agent. }\end{array}$ \\
\hline
\end{tabular}




\begin{tabular}{|c|c|}
\hline DAGNOSIS/ NURSING OUTCOMES & NURSING INTERVENTIONS \\
\hline \multicolumn{2}{|l|}{ PSYCHOBIOLOGICAL NEED - NUTRITION } \\
\hline $\begin{array}{l}\text { Effective breastfeeding } \\
\text { Exclusive breastfeeding } \\
\text { Interrupted breastfeeding } \\
\text { Impaired breastfeeding }\end{array}$ & $\begin{array}{l}\text { Scheduling follow-up appointment; } \\
\text { Assisting manual milking of the breast; } \\
\text { Assisting infants in correct grasping of the mother's breast; } \\
\text { Assessing the position of mothers and infants during breastfeeding; } \\
\text { Assessing weight gain; }\end{array}$ \\
\hline $\begin{array}{l}\text { Infant feeding behavior (effective/ } \\
\text { impaired) } \\
\text { Knowledge of mother/father/caregiver } \\
\text { about infant feeding (impaired/improved) } \\
\text { Difficulty breastfeeding } \\
\text { Lack of knowledge of mother/father/ } \\
\text { caregiver about infant feeding } \\
\text { Lack of knowledge of mother/father/ } \\
\text { caregiver about breastfeeding }\end{array}$ & $\begin{array}{l}\text { Assessing interpersonal relationships between mother/father/caregiver and infant during breastfeeding; } \\
\text { Demonstrating different positions for breastfeeding; } \\
\text { Demonstrating manual breast milking; } \\
\text { Referring mothers for appointment with a medical professional; } \\
\text { Referring infants for appointment with a medical professional; } \\
\text { Encouraging exclusive breastfeeding until the } 6^{\text {th }} \text { month; } \\
\text { Clarifying mother/father/caregiver's doubts about breastfeeding; } \\
\text { Encouraging breastfeeding on demand; } \\
\text { Examining the mothers'breast; } \\
\text { Guiding to keep bras clean and dry; } \\
\text { Guiding mothers to expose the breast to the sun before } 10 \text { a.m. and after } 4 \text { p.m, for } 10 \text { minutes; } \\
\text { Guiding the importance and benefits of breastfeeding; } \\
\text { Guiding mothers on the importance of depleting the breast before offering the other and in the next } \\
\text { breastfeeding start with the last breast offered; } \\
\text { Guiding mother/father/caregiver about breast milk composition; } \\
\text { Positioning infants correctly; } \\
\text { Performing compress and warm bath on the mother's breasts; } \\
\text { Perform manual milking of breasts whenever necessary; } \\
\text { Conducting home visit by the Health Team; } \\
\text { Performing measurement of anthropometric measurements; } \\
\text { Requesting family monitoring by a Community Health Agent. }\end{array}$ \\
\hline $\begin{array}{l}\text { Altered swallowing (reflux) (mild, } \\
\text { moderate, severe) } \\
\text { Improved swallowing (mild, moderate) } \\
\text { Normal swallowing }\end{array}$ & $\begin{array}{l}\text { Scheduling follow-up appointment; } \\
\text { Assessing the development and weight gain of infants; } \\
\text { Referring to appointment with a medical professional; } \\
\text { Referring to a nutritionist; } \\
\text { Guiding not to wear tight clothing on infants and discouraging umbilical band use; } \\
\text { Guiding not shake infants while breastfeeding and after breastfeeding; } \\
\text { Guiding diaper change, when necessary, to be performed before feedings, avoiding lying infants soon } \\
\text { after breastfeeding; } \\
\text { Guiding mother/father/caregiver about physiological reflux and gastroesophageal reflux disease; } \\
\text { Positioning infants in supine position to sleep; } \\
\text { Positioning infants with the head elevated after feeding for } 20 \text { minutes or until eructation; }\end{array}$ \\
\hline \multicolumn{2}{|l|}{ PSYCHOBIOLOGICAL NEED - ELIMINATION } \\
\hline $\begin{array}{l}\text { Risk of diarrhoea } \\
\text { Risk of impaired gastrointestinal system } \\
\text { function }\end{array}$ & $\begin{array}{l}\text { Scheduling follow-up appointment; } \\
\text { Assessing the infant's bowel habits; } \\
\text { Assessing signs of dehydration: mucosal moisture, turgor and skin elasticity, presence of tears and } \\
\text { diuresis, sunken eyes and depressed fontanelles; } \\
\text { Referring to appointment with a medical professional; } \\
\text { Identifying the duration, frequency, intensity, appearance, consistency and odor of feces; } \\
\text { Identifying the quantity and type of liquids or food ingested; } \\
\text { Guiding the replacement of liquids and electrolytes through Oral Rehydration Therapy (ORT); } \\
\text { Requesting family monitoring by a Community Health Agent. }\end{array}$ \\
\hline \multicolumn{2}{|c|}{ PSYCHOBIOLOGICAL NEED - SLEEP AND REST } \\
\hline $\begin{array}{l}\text { Risk of sudden infant death } \\
\text { Proper sleep } \\
\text { Poor sleep }\end{array}$ & $\begin{array}{l}\text { Scheduling follow-up appointment; } \\
\text { Guiding infants to sleep in supine position, even those with gastroesophageal reflux, with their feet } \\
\text { leaning against the lower edge of the crib; } \\
\text { Guiding so that the mattress is firm and the size of the crib; } \\
\text { Guiding so that the car safety seat and stroller are not used for regular sleep; } \\
\text { Guiding so that the bed is not shared with parents; } \\
\text { Guiding the relationship of sudden death and the mother's smoking habits as well as use of drugs } \\
\text { and alcohol; } \\
\text { Strengthening breastfeeding; } \\
\text { Using only a sheet to cover infants, not covering their head and wear clothes for their heating. }\end{array}$ \\
\hline
\end{tabular}




\begin{tabular}{|c|c|}
\hline DAGNOSIS/ NURSING OUTCOMES & NURSING INTERVENTIONS \\
\hline \multicolumn{2}{|l|}{ PSYCHOBIOLOGICAL NEED - BODY CARE } \\
\hline $\begin{array}{l}\text { Mother/parent/caregiver's ability to perform } \\
\text { improved care } \\
\text { Mother/father/caregiver's knowledge about } \\
\text { improved infant body hygiene } \\
\text { Mother/father/caregiver's knowledge about } \\
\text { improved oral hygiene } \\
\text { Lack of mother/father/caregiver knowledge } \\
\text { about infant care } \\
\text { Lack of mother/father/caregiver knowledge } \\
\text { about oral hygiene } \\
\text { Hygiene (impaired/improved) } \\
\text { Improved skin integrity } \\
\text { Risk of mother/parent/caregiver's ability to } \\
\text { perform impaired care } \\
\text { Risk of impaired skin integrity }\end{array}$ & $\begin{array}{l}\text { Scheduling follow-up appointment; } \\
\text { Assessing skin integrity; } \\
\text { Assessing hygiene state; } \\
\text { Demonstrating technique for performing body, oral and genital hygiene, } \\
\text { Encouraging body and oral hygiene; } \\
\text { Guiding mother/father/caregiver about the importance of body and oral hygiene; } \\
\text { Guiding mother/father/caregiver to wear clothes appropriate to the room temperature; } \\
\text { Performing genital region hygiene with each diaper change; } \\
\text { Performing oral hygiene of infants, gums and tongue, and after eruption of incisors, at least once a } \\
\text { day; } \\
\text { Conducting home visit by the health team; } \\
\text { Requesting family monitoring by a Community Health Agent; } \\
\text { Changing diaper after bowel movements and whenever necessary. }\end{array}$ \\
\hline \multicolumn{2}{|c|}{ PSYCHOBIOLOGICAL NEED - SKIN AND MUCOUS MEMBRANE INTEGRITY } \\
\hline $\begin{array}{l}\text { Oral candidiasis (mild, moderate, severe) } \\
\text { Improved oral candidiasis } \\
\text { Mother/father/caregiver's knowledge } \\
\text { about appropriate candidiasis } \\
\text { Lack of mother/father/caregiver knowledge } \\
\text { about candidiasis } \\
\text { Improved oral mucosa integrity } \\
\text { Risk of impaired oral mucosa integrity }\end{array}$ & $\begin{array}{l}\text { Scheduling follow-up appointment; } \\
\text { Assessing oral cavity; } \\
\text { Assessing the mothers' breast and nipple; } \\
\text { Demonstrating technique for performing oral hygiene; } \\
\text { Encouraging oral cavity hygiene to promote cleansing, massage the gum and accustom infants to } \\
\text { mouth manipulation; } \\
\text { Guiding mothers to avoid using tampons in the breast; } \\
\text { Guiding mothers to sanitize the breast after feeding; } \\
\text { Guiding mother/father/caregiver to perform oral hygiene of infants after feeding; } \\
\text { Guiding mother/father/caregiver about pacifier damage and bottle use; } \\
\text { Guiding mother/father/caregiver to sanitize the bottle, pacifiers and toys that come into contact with } \\
\text { the infant's mouth; } \\
\text { Guiding infant oral health care; } \\
\text { Prescribe medication for infants according to the institutional protocol; } \\
\text { Prescribe medication for application to the mothers' breasts after breast hygiene following an } \\
\text { Institutional Protocol. }\end{array}$ \\
\hline $\begin{array}{l}\text { Heat erythema (mild, moderate, severe) } \\
\text { Improved heat erythema } \\
\text { Mother/father/caregiver's knowledge of } \\
\text { adequate heat erythema } \\
\text { Lack of mother/father/caregiver knowledge } \\
\text { about heat erythema } \\
\text { Improved skin integrity } \\
\text { Risk of impaired skin integrity } \\
\text { Diaper erythema (mild, moderate, severe) } \\
\text { Improved diaper erythema } \\
\text { Mother/father/caregiver's knowledge } \\
\text { about appropriate diaper erythema }\end{array}$ & $\begin{array}{l}\text { Scheduling follow-up appointment; } \\
\text { Relieving excess clothing; } \\
\text { Assessing skin integrity, lesion characteristics and skin around it; } \\
\text { Demonstrating technique to perform intimate hygiene of infants; } \\
\text { Guiding mother/father/caregiver to care for skin lesion; } \\
\text { Avoiding direct contact of the infant's skin with woolen clothing; } \\
\text { Encouraging body hygiene; } \\
\text { Guiding mother/father/caregiver about the importance of body hygiene; } \\
\text { Guiding mother/father/caregiver to use appropriate clothing at room temperature; } \\
\text { Scheduling follow-up appointment; } \\
\text { Assessing skin integrity; } \\
\text { Assessing characteristics of the lesion and the skin around it; } \\
\text { Demonstrating technique to perform genital hygiene; }\end{array}$ \\
\hline $\begin{array}{l}\text { Lack of knowledge of mother/father/ } \\
\text { caregiver about diaper erythema } \\
\text { Improved skin integrity } \\
\text { Risk of impaired skin integrity }\end{array}$ & $\begin{array}{l}\text { Referring to appointment with a medical professional; } \\
\text { Avoiding using a wet wipe; } \\
\text { Encouraging the infant's body hygiene; } \\
\text { Guiding mother/father/caregiver to care for skin lesion; } \\
\text { Guiding mother/father/caregiver about the importance of body hygiene; } \\
\text { Guiding to expose the affected area to the sun (before } 10 \text { a.m. and after } 4 \text { p.m.), for } 15 \text { minutes; } \\
\text { Performing genital region hygiene at each diaper change; } \\
\text { Requesting family monitoring by a Community Health Agent; } \\
\text { Suspending use of hygiene product that causes erythema; } \\
\text { Changing diaper after evacuations and whenever necessary; } \\
\text { Changing the diaper brand; } \\
\text { Using age-appropriate hygiene products. }\end{array}$ \\
\hline
\end{tabular}




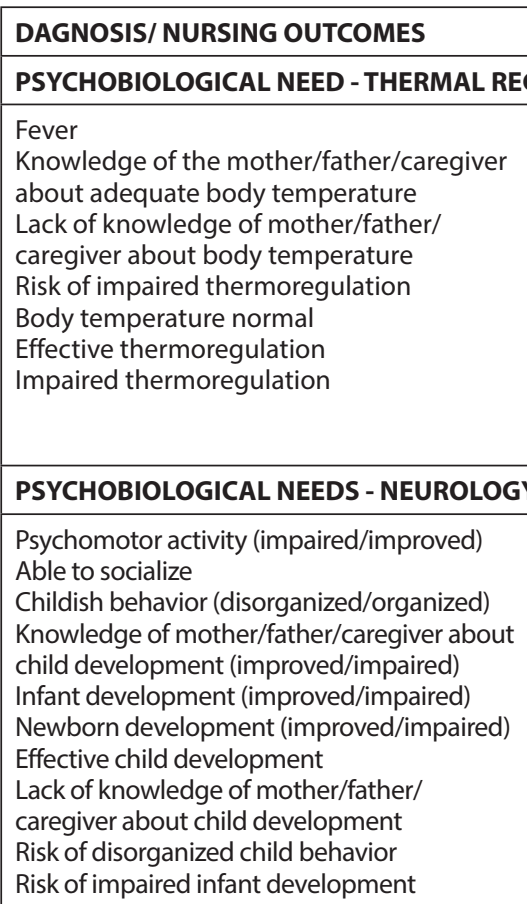

NURSING INTERVENTIONS

\section{PSYCHOBIOLOGICAL NEED - THERMAL REGULATION}

Administering antipyretic in accordance with an Institutional Protocol;

Applying water compress at room temperature;

Relieving excess clothing;

Consulting mother/father/caregiver if infants took medication for fever;

Consulting mother/father/caregiver about what medication infants usually take for fever;

Referring to appointment with a medical professional;

Monitoring and recording body temperature;

Guiding mother/father/caregiver of infants with a temperature above $38^{\circ} \mathrm{C}$ to seek health/emergency services;

Guiding mother/father/caregiver about shower bath;

\section{PSYCHOBIOLOGICAL NEED - IMMUNOLOGICAL REGULATION}

Inflammation (mild, moderate, severe) Improved inflammation

Adherence to the immunization regimen

Improved skin integrity

Non-adherence to the immunization

regimen

Risk of impaired skin integrity

Scheduling follow-up appointment

Assessing skin integrity;

Assessing characteristics of the lesion and the skin around it;

Referring to appointment with a medical professional;

Encouraging body hygiene;

Guiding mother/father/caregiver about the importance of body hygiene;

Advising the importance of vaccines and to keep vaccination scheduling up to date;

Requesting family monitoring by a Community Health Agent;

Using scissors or nail clippers with a rounded tip and for exclusive use of for infants to cut the nails;

Wearing clothing appropriate to the temperature;

Verifying the infant's vaccination status.

Scheduling follow-up appointment;

Assessing body hygiene state;

Assessing umbilical stump skin integrity;

Demonstrating technique for umbilical stump hygiene;

Performing umbilical stump hygiene with $70 \%$ alcohol whenever necessary;

Keeping the umbilical stump clean and dry;

Guiding mother/father/caregiver about basic care with the umbilical stump and body hygiene;

Guiding mother/father/caregiver not to use umbilical band and other products on the umbilical stump;

Requesting family monitoring by a Community Health Agent.

\section{PSYCHOBIOLOGICAL NEEDS - CELL GROWTH REGULATION}

Delayed growth (or growth delay)

Growth within normal limits

Risk of delayed growth (or delayed growth)

Risk of disproportionate growth
Scheduling follow-up appointment;

Measuring the anthropometric parameters: weight, height, head circumference, thoracic and

abdominal;

Performing bone, dental and physical-motor development assessment;

Recording the information in the Child Health Booklet and assessing the related graphics;

Observing breastfeeding (infant position, grasp, suction and the mother's breast);

Guiding mother/father/caregiver on a routine of childcare appointments;

Verifying with mother/father/caregiver what they think and/or perceive about the infant's growth process.

\section{PSYCHOBIOLOGICAL NEEDS - VASCULAR REGULATION}

Altered skin color (Jaundice - mild,

moderate, severe)

Normal skin color

Knowledge of the mother/father/caregiver

about proper skin color

Lack of knowledge of the mother/father/

caregiver about skin color
Scheduling follow-up appointment;

Increasing the frequency of breast milk supply;

Assessing jaundice location and intensity;

Assessing breastfeeding;

Referring to appointment with a medical professional;

Encouraging breastfeeding on demand;

Guiding mother/father/caregiver about jaundice;

Sunbathing with infants without clothes, before 10 a.m. and after 4 p.m, for up to 10 minutes; 


\begin{tabular}{|c|c|}
\hline DAGNOSIS/ NURSING OUTCOMES & NURSING INTERVENTIONS \\
\hline \multicolumn{2}{|l|}{ PSYCHOSOCIAL NEED - SAFETY/LOVE } \\
\hline $\begin{array}{l}\text { Adaptation (improved/impaired) } \\
\text { Adjustment of mother/father/caregiver } \\
\text { (improved/impaired) } \\
\text { Affective mother/father/caregiver-infant } \\
\text { bonding (effective/impaired) } \\
\text { Risk of impaired emotional attachment of } \\
\text { mother/father/caregiver-infant }\end{array}$ & $\begin{array}{l}\text { Scheduling follow-up appointment; } \\
\text { Referring to a social worker and/or psychologist; } \\
\text { Encouraging interaction of mother/father/caregiver with infants; } \\
\text { Identifying and preventing postpartum depression and refer the mother for treatment, if necessary; } \\
\text { Identifying families at risk (domestic abuse, alcohol or drug addiction, lack of family support, } \\
\text { adolescent parents with a fragile support network, etc.); } \\
\text { Guiding on the importance of developing affective bond between mother/father/caregiver and infant } \\
\text { and its relationship with adequate growth and development, construction of personality, affective } \\
\text { relationships and sociability; } \\
\text { Guiding mother/father/caregiver about doubts regarding infant care; } \\
\text { Promoting breastfeeding and support for its effectiveness; } \\
\text { Conducting home visit by the health team; } \\
\text { Requesting family monitoring by a Community Health Agent; } \\
\text { Verifying the existence of difficulties in mother/father/caregiver adaptation in relation to the arrival of } \\
\text { infants. }\end{array}$ \\
\hline \multicolumn{2}{|c|}{ PSYCHOSOCIAL NEED - PARTICIPATION/ATTENTION } \\
\hline $\begin{array}{l}\text { Improved parenting knowledge of parent/ } \\
\text { caregiver }\end{array}$ & $\begin{array}{l}\text { Scheduling follow-up appointment; } \\
\text { Referring to a social worker and/or psychologist; } \\
\text { Encouraging interaction of mother/father/caregiver with infants; }\end{array}$ \\
\hline $\begin{array}{l}\text { Lack of knowledge of mother/father/ } \\
\text { caregiver about parenting } \\
\text { Parenting (effective/impaired) } \\
\text { Risk of impaired parenting }\end{array}$ & $\begin{array}{l}\text { Identifying families at risk (domestic abuse, alcohol or drug addiction, lack of family support, } \\
\text { adolescent parents with a fragile support network, etc.); } \\
\text { Promoting reflection with mother/father/caregiver on family relationships, demonstrating the } \\
\text { importance for the infant's emotional maturation; } \\
\text { Conducting home visits by the health team; } \\
\text { Requesting family monitoring by a Community Health Agent. }\end{array}$ \\
\hline
\end{tabular}

(80.2\%), at nutritional risk (2.1\%) and with some degree of malnutrition (17.7\%). Therefore, NC is important in childcare in the identification and early referral of infants, evidenced by the referrals made by the nurse to the pediatrician, when changes in the physical examination (70.6\%) and when infants received a prescription of vitamin A and iron (19.6\%) $)^{(20)}$.

Diarrheal diseases were the second leading cause (29.2\%) of morbidity in the study ${ }^{(18)}$ carried out with high-risk neonates. Of a total of $70.8 \%$ of children who fall ill until the age of six months, $12.5 \%$ required hospitalization, reinforcing the importance of the nursing diagnoses and results identified and selected for the present subset related to elimination ${ }^{(18)}$.

The terminology subset is an essential tool for Childcare NC, as it facilitates the investigation of factors that influence the health of infants and contribute to the nurses' clinical reasoning and decision making, aiming at the protection and promotion of child health ${ }^{(9)}$. Furthermore, early identification and intervention of problem situations are essential to prevent the progress of a clinical condition and its worsening ${ }^{(20)}$.

Growth assessment is important for monitoring infants' health and nutrition conditions, carried out through clinical and social history, physical examination and data provided by parents. Child development assessment occurs according to the development milestones, i.e., it refers to the construction of human identity evidenced in the progressive transformations, maturation, learning, psychic, and social aspects ${ }^{(21-22)}$.

The plurality of nursing diagnoses and results identified in this subset are related to the focus of child growth and development (cell growth, nutrition, neurological regulation, immune regulation, thermal regulation, sleep, and rest). These findings reinforce a study ${ }^{(3)}$ that considered Nursing Process (NP) implementation relevant to children in their different phases, thus building statements of nursing diagnoses by steps of child growth and development.
Among the psychobiological needs, situations that affect the infant's skin and mucous membrane integrity were also identified. Nursing diagnoses and results focus on child morbidity situations, meeting the local health diagnosis. In this regard, problems related to skin and mucous membrane integrity were observed in other studies ${ }^{(6,20,23-24)}$, which selected these nursing diagnoses, mainly diaper dermatitis, miliaria, heat erythema, diaper erythema, perineal and oral candidiasis.

Psychosocial needs for love, security, attention and participation related to family interactions were listed in the subset presented here. These needs are aligned with the aspects that involve the infant's development and that occur in a relatively short period of time, requiring the effective participation of the family. Situations related to parenting reflect behavioral manifestations in childhood, in which practices involving parent engagement in care, in communication, expression of affection and in constructive conflict resolution strategies are considered positive practices ${ }^{(6,25)}$.

Validation by nurses consolidates EBP and brings the terms that make up the subset closer to the practical reality, thus contributing to infant health care qualification through Childcare NC.

$I{ }^{\infty}{ }^{\circledR}$ use assists nurses in clinical reasoning in decision making through EBP and registration of professional practice, contributing to the prerogatives of Resolution COFEN (Conselho Federal de Enfermagem - Brazil's Federal Council of Nursing) 358 of $2009^{(26)}$. Moreover, NC guides care and documents the nurses' practice, and implementing a care based on a nursing theory entrusts theoretical and scientific foundation to its actions ${ }^{(14,27)}$.

\section{Limitations of the Study}

This study resulted in diagnoses, results and nursing interventions centered on psychobiological and psychosocial needs, with a focus on morbidities and infant growth and development. In 
this regard, it is necessary to advance studies on the theme to create and propose new terms that contemplate other needs provided in Theory, in order to complement this subset and qualify child care in $\mathrm{PHC}$.

\section{Contributions to nursing}

This subset cooperates with the ICN recommendation in building ICNP ${ }^{\circledR}$ catalogs. It contributes to the description of professional practice through a unified nursing language. In addition, it enables effective and safe care for infants and their families through the implementation of systematic actions; therefore, it contributes to early detection of health problems and providing care aimed at health promotion, resulting in quality of care.

\section{FINAL CONSIDERATIONS}

The ICNP ${ }^{\circledR}$ terminology subset, developed in this study, is an important tool in PHC due to its compatibility with nurses' experiences during Childcare NC. Moreover, using a SLS organizes the nurses' work process, contributing to safe and effective care for infants.
Subsets also collaborate to implement a systematic childcare $\mathrm{NC}$ and for the use of specific nursing diagnoses, results and interventions for infants, contributing to NC registration; internationally recognized terminology of specialized nursing practice languages is applied, favoring communication between health professionals, with a view to comprehensive care.

It is necessary to incorporate the subset into care protocols, in order to strengthen the guidance and organization of professional practice, given its importance in contributing to quality and safety of child care through evidence-based actions.

\section{FUNDING}

This study was funded by Coordenação de Aperfeiçoamento de Pessoal de Nível Superior - Brazil (CAPES -) and the Conselho Federal de Enfermagem - Brazil (COFEN) Process n²7/2016.

\section{ACKNOWLEDGMENT}

For Professor Dra. Telma Ribeiro Garcia (in memoriam) for her contributions and CAPES/COFEN for the support and promotion of research.

\section{REFERENCES}

1. Wilson D, Hockenberry MJ. Wong: manual clínico de Enfermagem pediátrica. 8. ed. Rio de Janeiro: Elsevier; 2012.

2. Góes FGB, Silva MA, Paula GK, Oliveira LPM, Mello NC, Silveira SSD. Contribuições do enfermeiro para boas práticas na puericultura: revisão integrativa da literatura. Rev Bras Enferm. 2018;71(supl.6):2808-17. doi: 10.1590/0034-7167-2018-0416

3. Dantas AMN, Gomes GLL, Silva KL, Nóbrega MML. Diagnósticos de enfermagem para as etapas do crescimento e desenvolvimento de crianças utilizando a CIPE ${ }^{\circledR}$. Rev Eletr Enf. 2016;18:e1165. doi: 10.5216/ree.v18.35524

4. Instituto Brasileiro de Geografia e Estatística IBGE. Estimativas da População [Internet]. 2019 [cited 2019 Feb 12]. Available from: https:// www.ibge.gov.br/estatisticas/sociais/populacao/ 9103-estimativas-de-populacao.html?edicao=22367\&t=resultados

5. Departamento de Informática do SUS. DATASUS: Informação de Saúde (TABNET). Brasília: 2008. Epidemiológicas e morbidade [Internet]. 2019 [cited 2019 May 9]. Available from: http://www2.datasus.gov.br/DATASUS/index.php?area=02

6. Costa P, Duarte, AP, Belela-Anacleto ASC, Andrade PR, Balieiro MMFG, Veríssimo MLOR. Diagnósticos de enfermagem em consultas de atenção primária à saúde de recém-nascidos. Rev Bras Enferm. 2018;71(6):2961-8. doi:10.1590/0034-7167-2017-0954

7. Yakuma MS, Neill S, Mello DF. Nursing strategies for child health surveillance. Rev. Latino-Am. Enfermagem. 2018;26(e3007). doi: $10.1590 / 1518-8345.2434 .3007$

8. International Council of Nurses ICN. Guidelines for ICNP ${ }^{\circledR}$ catalogue development. Geneva: ICN; 2018[Internet]. 2018. [cited 2018 Dec 7]. Available from: https://www.icn.ch/what-we-do/projects/ehealth-icnp/about-icnp/icnp-catalogues

9. Primo CC, Resende FZ, Garcia TR, Duran ECM, Brandão MAG. Subconjunto terminológico da CIPE ${ }^{\circledR}$ para assistência à mulher e à criança em processo de amamentação. Rev Gaúcha Enferm. 2018;39:e2017-0010. doi: 10.1590/1983-1447.2018.2017-0010

10. Liu L, Coenen A, Tao H, Jansen KR, Jiang AL. Developing a prenatal nursing care International Classification for Nursing Practice catalogue. Int Nurs Rev. 2017;64(3):371-8. doi: 10.1111/inr.12325

11. Horta WA. Processo de Enfermagem. 1. ed. Rio de Janeiro: Guanabara Koogan; 2011.

12. Kitzinger J. Grupos Focais. In: Pope C, Mays N. organizadores. Pesquisa qualitativa na atenção à saúde. 3. ed. Porto Alegre: Artmed; 2009.

13. International Organization for Standardization ISO. Health informatics-Categorial structures for representation of nursing diagnoses and nursing actions in terminological systems[Internet]. Geneva: ISO; 2014. 2014 [cited 2019 May 20] Available from: https://www.iso.org/ standard/59431.html

14. Garcia TR. Organizador. Classificação Internacional para a prática de enfermagem CIPE ${ }^{\circledR}$ Versão 2017. Porto Alegre: Artmed; 2018.

15. Polit-O'hara D, Beck CT. Fundamentos de pesquisa em enfermagem: avaliação de evidências para prática da enfermagem. 7. ed. Porto Alegre: Artes Médicas; 2011.

16. Prefeitura do Município de Caçador, Secretaria Municipal de Saúde. Departamento de Tecnologia da Informação. Relatórios. 2018. 
17. Departamento de Informática do SUS. DATASUS: Informação de Saúde (TABNET). Brasília: 2008. Epidemiológicas e morbidade [Internet]. 2018 [cited 2018 Apr 10]. Available from: http://www2.datasus.gov.br/DATASUS/index.php?area=02

18. Gauteiro DP, Irala DA, Cezar-Vaz MR. Puericultura em Enfermagem: perfil e principais problemas encontrados em crianças menores de um ano. Rev Bras Enferm. 2012;65(3):508-13. doi: 10.1590/S0034-71672012000300017

19. Castro ACO, Duarte ED, Diniz IA. Intervenção do Enfermeiro às crianças atendidas no ambulatório de seguimento do recém-nascido de risco. Rev Enferm C Oeste Min. 2017;7:e1159. doi: 10.19175/recom.v7i0.1159

20. Luciano TS, Nóbrega MML, Saparolli ECL, Barros ALBL. Cross Mapping of Nursing diagnoses in Infant Health Using the International Classification of Nursing Practice. Rev Esc Enferm USP. 2014;48(2):250-6. doi: 10.1590/S0080-623420140000200008

21. Martins CBG, Barcelon AA, Lima FCA, Gaíva MAM. Profile of morbidity and mortality in at-risk newborns. Cogitare Enferm. 2014;19(1):111-7. doi: 10.5380/ce.v19i1.35966

22. Monteiro FPM, Araujo TL, Ximenes LB, Vieira NFC. Ações de Promoção da saúde realizadas por enfermeiros na avaliação do crescimento e desenvolvimento infantil. Cien Enferm. 2014; 20(1):97-110. doi: 10.4067/S0717-95532014000100009

23. Viera CS, Silva RMM, Toso BRGO. O desenvolvimento infantil. In: Toso BRGO, Vieira CS, Fiewski MFC. Organizadores. Cuidado de Enfermagem ao neonato, à criança e ao adolescente na Atenção Primária à Saúde. Cascavel, PR: Edunioeste; 2017. p.151-170.

24. Schimdt B, Staudt ACP, Wagner A. Intervenções para promoção de práticas parentais positivas: uma revisão integrativa. Contextos Clín. 2016;9(1):2-18. doi: 10.4013/ctc.2016.91.01

25. Conselho Federal de Enfermagem (COFEN) [Internet]. Brasília: 2009 [cited 2019 Jan 31]. Resolução no 358 de 2009. Available from: http:// www.cofen.gov.br/resoluo-cofen-3582009 4384.html

26. Kahl C, Meirelles BHS, Lanzoni GMM, Koerich C, Cunha KS. Actions and interactions in clinical nursing practice in Primary Health Care. Rev Esc Enferm USP. 2018;52:e03327. doi: 10.1590/s1980-220x2017025503327

27. Andrade LZC, Chaves DBR, Silva VM, Beltrão BA, Lopes MVO. Respiratory nursing diagnoses for children with acute respiratory infection. Acta Paul Enferm. 2012; 25(5):713-20. doi: 10.1590/S0103-21002012000500011 